\title{
Mammary fibroadenomatoid hyperplasia in a heifer
}

\author{
Lorena Ferreira Silva ${ }^{1}$ Luiz Antonio Franco da Silva ${ }^{2}$ Rogério Elias Rabelo ${ }^{2}$ \\ Wanessa Patrícia Rodrigues da Silva ${ }^{2}$ Geovanni Dantas Cassali ${ }^{3}$

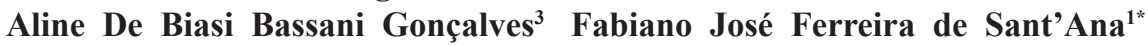

\footnotetext{
'Laboratório de Diagnóstico Patológico Veterinário, Hospital Veterinário de Grandes Animais, Universidade de Brasília (UnB), 70636-020, Brasília, DF, Brasil. E-mail: santanafjf@yahoo.com. *Corresponding author.

${ }^{2}$ Escola de Veterinária e Zootecnia, Universidade Federal de Goiás (UFG), Goiânia, GO, Brasil.

${ }^{3}$ Instituto de Ciências Biológicas (ICB), Universidade Federal de Minas Gerais (UFMG), Belo Horizonte, MG, Brasil.
}

ABSTRACT: This manuscript described the anatomopathological and immunohistochemical findings in a rare case of mammary fibroadenomatoid hyperplasia in a 12-month-old Holstein heifer. A yellow, multilobulated, firm $20 \mathrm{~cm} \times 9 \mathrm{~cm} \times 6.5 \mathrm{~cm}$ mass affecting the right quarters of the udder was observed. Total mastectomy was performed. Microscopic evaluation revealed severe hyperplasia of the mammary epithelium and numerous well-differentiated and mildly pleomorphic acini. Additionally, moderate proliferation of the fibrous connective tissue and the myoepithelial cells near the proliferating acini was evident. About $50 \%$ of the proliferating epithelial cells showed positive nuclear labeling for estrogen and progesterone receptors, and approximately one-third were positive for Ki-67. In addition, the myoepithelial cells exhibited diffuse nuclear immunoreactivity for p63. Based on the clinical, morphologic, and immunohistochemical findings, a diagnosis of mammary fibroadenomatoid hyperplasia with probable influence of ovarian steroids was made.

Key words: mammary hyperplasia, estrogen, progesterone, diseases of cattle.

Hiperplasia fibroadenomatoide mamária em uma novilha

RESUMO: Este artigo descreve os achados anatomopatológicos e imuno-histoquímicos de um caso raro de hiperplasia fibroadenomatoide mamária em uma novilha Holandesa de 12 meses. Observou-se uma massa amarelada, firme, multilobulada, medindo $20 x 9$ x 6,5cm e afetando os quartos direitos do úbere. Mastectomia total foi realizada. Microscopicamente, notou-se hiperplasia acentuada do epitélio mamário e numerosos ácinos levemente pleomórficos e bem diferenciados. Proliferação moderada do tecido conjuntivo fibroso e das células mioepiteliais próximos aos ácinos proliferados era também evidente. Aproximadamente 50\% das células epiteliais proliferadas mostraram marcação nuclear positiva para receptores de estrógeno e progesterona e cerca de um terço dessas células era positivo para Ki-67. Além disso, as células mioepiteliais exibiram reação nuclear e difusa para p63. Com base nos achados clínicos, morfológicos e imuno-histoquímicos, firmou-se o diagnóstico de hiperplasia fibroadenomatoide mamária com provável influência de esteroides ovarianos.

Palavras-chave: hiperplasia mamária, estrógeno, progesterona, doenças de bovinos.

Progressive lesions of the mammary gland are common in dogs and cats, but are rarely observed in farm animals. Infrequent cases of mammary neoplasms have been reported in cattle (POVEY \& OSBORNE, 1969; MINA et al., 1994), mares (HIRAYAMA et al., 2003; BRITO et al., 2008), water buffalo(MANDAL \& IYER, 1969), and goats (SINGH \& IYER, 1972); whereas, hyperplastic changes have been observed in cattle (HONG et al., 1994) and water buffalo (SANT'ANA et al., 2014). Mammary epithelial hyperplasia is classified into three distinct types: lobular (arising from the intralobular ducts), ductal (arising from the extralobular ducts), and adenosis (CASSALI et al., 2011). Another type named fibroadenomatoid hyperplasia has been reported in women as a rare benign lesion characterized by prominent hyperplasia of the epithelial cells and multifocal lobulocentric proliferation of the fibrous stroma, including the myoepithelial components (WU \& CHEN, 2001). Fibroadenomatoid hyperplasia may occur as a localized or diffuse lesion; it is observed in approximately $5-7 \%$ of all benign surgical biopsy samples from Japanese and American women (HANSON et al., 1987). In humans, this type of lesion was formerly known as fibroadenomatosis, sclerosing lobular hyperplasia, and fibroadenomatoid change or mastopathy (HANSON et al., 1987; WU \& CHEN, 2001). This condition was recently observed in three young water buffalo and endocrine influences were suggested in the pathogenesis of the 
lesion (SANT'ANA et al., 2014). The objective of the current study was to evaluate the clinicopathological and immunohistochemical findings of a rare case of mammary fibroadenomatoid hyperplasia in a heifer.

A one-year-old, intact Holstein heifer presented with a painless swelling in the udder affecting the right quarters that had progressively evolved over four days (Figure 1A). The animal was from a mixed herd of 40 heifers and cows that were raised in the county of Goiânia, state of Goiás, Brazil. Treatment with penicillin, anti-inflammatory medications, and showers with running water for three months was unsuccessful. The entire gland was surgically removed. Grossly, the excised mammary gland contained a yellowish, homogeneous, firm mass with spongy areas, measuring $20 \mathrm{~cm} \times 9 \mathrm{~cm} \times 6.5 \mathrm{~cm}$ (Figure 1B). The cut surfaces of the mammary lesion showed numerous coalescing lobules separated by fibrous septa (Figure 1B). There was no evidence of mammary lesion recurrence at eight months after the surgical removal.

Samples of the mammary lesions were collected, fixed in $10 \%$ formalin for $24 \mathrm{~h}$, and processed using routine methods for histological evaluation. Sections were stained with hematoxylin and eosin, and immunohistochemical staining (IHC) was performed using a biotin-peroxidase system, with labeling of the secondary antibody with a polymer (Advance HRP enzyme, Dako North America Inc., Carpinteria, CA, USA) and diaminobenzidine (DAB) as the chromogen. Antigen retrieval was performed by pressurized heating at $125^{\circ} \mathrm{C}$ in a citrate-buffered solution at $\mathrm{pH} 6.0$ (Dako North America Inc., Carpinteria, CA) for Ki-67 and $\mathrm{p} 63$, or in an ethylenediamine tetra-acetic acid buffer solution at $\mathrm{pH} 9.0$ for the estrogen receptor (ER) and progesterone receptor (PR) (Dako North America Inc., Carpinteria, CA, USA). To block the endogenous peroxidase activity, the slides were incubated in a solution of $\mathrm{H}_{2} \mathrm{O}_{2}(3 \%)$ in methyl alcohol. The reagents were added manually, with 1-hour incubation for the monoclonal primary antibodies and a 30-minute incubation for the other reagents with the exception of DAB, which was incubated for $5 \mathrm{~min}$. The IHC antibody panel is described in table 1 . The IHC sections were counterstained using Harris hematoxylin. The positive controls for IHC consisted of normal mammary glands. For the negative controls, normal serum (Ultra V Block, NeoMarkers Inc., Fremont, CA, USA) was added instead of the primary antibodies. Nuclear staining (Ki-67, p63, ER, and PR) was assessed by determining the percentage of positive cells among 500 cells (viewed under $400 \times$ magnification).
Microscopic evaluation demonstrated severe proliferation of the mammary epithelium with the formation of numerous, well-differentiated, and mildly pleomorphic tubules and their associated ducts. The acini had 1-4 layers of columnar or cuboidal epithelial cells and were moderately dilated. The cell borders were indistinct. The cytoplasm was slightly eosinophilic, and the nucleus was oval, finely granular, and hypochromatic. Mild anisocytosis, anisokaryosis, and rare mitosis were observed. Moderate proliferation of the fibrous connective tissue and the myoepithelial cells was observed among the proliferated acini. Few lymphocytes were detected in the fibrous stroma. Few hyperplasic mammary tubules had moderate ectasia and were occasionally filled with amorphous eosinophilic material.

About $50 \%$ of the proliferated epithelial cells demonstrated moderate to strong positive nuclear labeling for ER (Figure 1C) and PR (Figure 1D). In addition, approximately one-third of these cells were positive for Ki-67 (Figure 1F). The myoepithelial cells exhibited diffuse, moderate nuclear immunoreactivity for p63 (Figure 1E). Based on the morphologic and immunohistochemical findings, a diagnosis of mammary fibroadenomatoid hyperplasia with probable influence of ovarian steroids was made.

Mammary hyperplasia is diagnosed commonly in company animals, but rarely in herbivores (HONG, 1994; MISDORP, 2002). Pathogenesis of this proliferative lesion is not completely understood, but endocrine changes are likely involved in canine and feline females (MISDORP, 2002). Recently, three cases of mammary diffuse fibroadenomatoid hyperplasia were diagnosed in water buffalo present in Midwestern and Southern Brazil, and the immunohistochemical evaluation suggested probable hormonal influence (SANT'ANA et al., 2014). An isolated case of mammary nodular hyperplasia in a 13-year-old cow was attributed to chronic irritation associated with chronic mastitis (HONG, 1994). This author considered hyperplasia to be a regenerative response to counteract for the affected mammary tissue. In the current case, there were no significant inflammatory lesions associated with the fibroadenomatoid hyperplasia. Similar to the previously reported cases in bubaline females (SANT'ANA et al., 2014), ovarian endocrine influence on the hyperplasia was suspected, given the IHC-labeling results (positive for estrogen and progesterone receptors). In contrast, the feline mammary diffuse fibroepithelial hyperplasia commonly presents with high concentrations of 

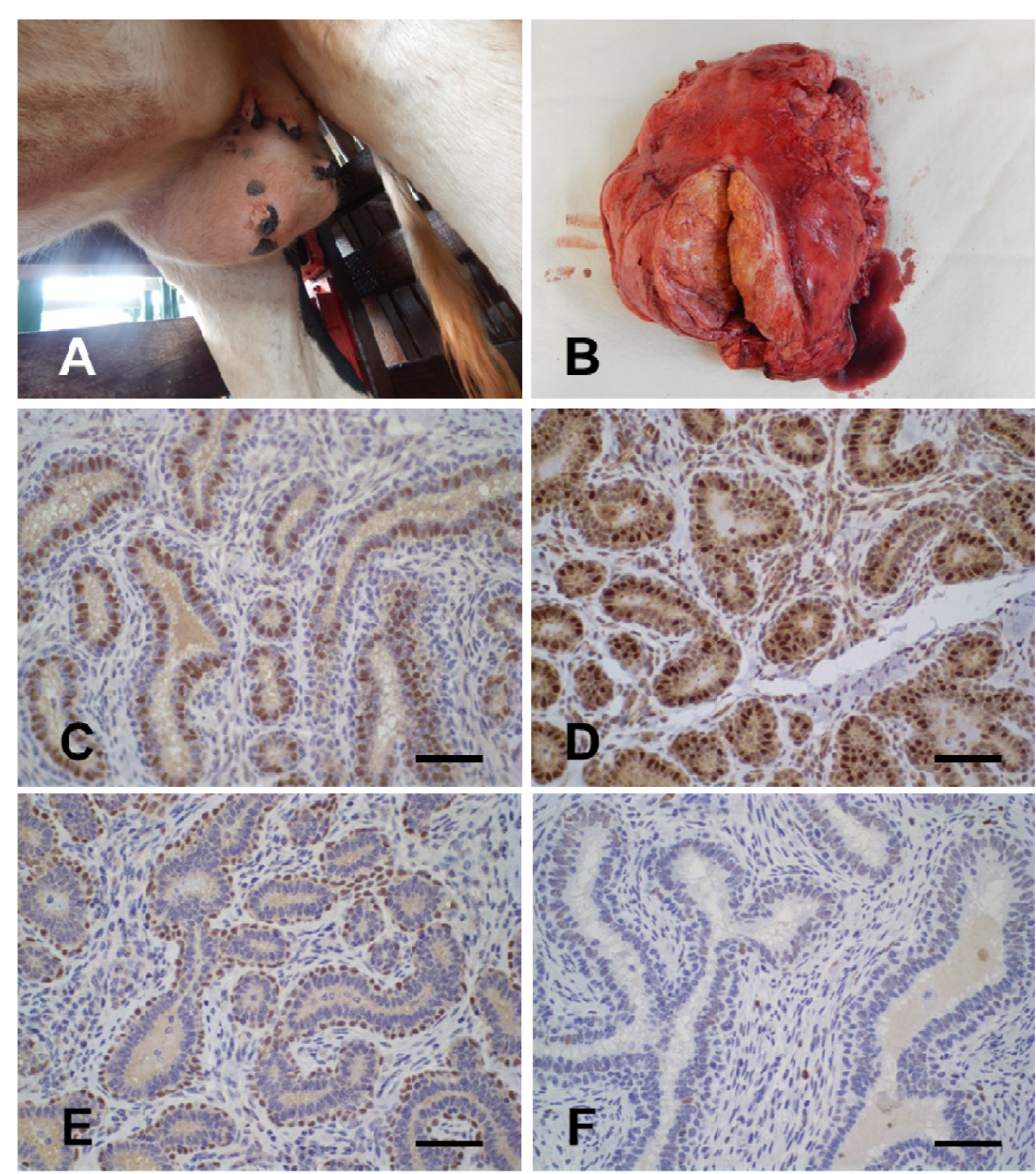

Figure 1 - Mammary fibroadenomatoid hyperplasia in a heifer. A. There is a moderate enlargement of the right quarters of the udder. B. Cut surface of this mass shows a yellow, multilobulated, and firm tissue. Moderate and severe positive nuclear labeling for estrogen (C) and progesterone (D) receptors in the affected epithelium, respectively. Immunohistochemical reaction (IHC) with 3,3'-diaminobenzidine (DAB) chromogen and hematoxylin counterstain. Bar $=60 \mu \mathrm{m}(\mathrm{C})$ and $80 \mu \mathrm{m}(\mathrm{D})$. E. There is moderate positive nuclear staining for myoepithelial cells (p63). Immunohistochemical reaction (IHC) with 3,3'-diaminobenzidine (DAB) chromogen and hematoxylin counterstain. Bar $=80 \mu \mathrm{m}$. F. Few epithelial cells present mild, positive reaction for Ki-67. Immunohistochemical reaction (IHC) with 3,3'-diaminobenzidine (DAB) chromogen and hematoxylin counterstain. Bar $=60 \mu \mathrm{m}$.

only progesterone receptors (MISDORP, 2002). In the present study, the immunoreactivity tests demonstrated that one-third of the epithelial cells were positive for Ki-67. Similar results have been observed in feline mammary hyperplasia (PEREIRA et al., 2004). However, in cases of benign mammary lesions in humans (GERDES et al., 1986) and canines (PEÑA et al., 1998), the immunoreactivity for Ki-67 was low. In this study, the positivity for $\mathrm{p} 63$ highlighted the proliferation of myoepithelial cells associated with epithelial hyperplasia.

The affected heifer in the current study was young (1 year old). This condition was also detected in young water buffalo (10 to 12 months old) with morphologic changes in the mammary gland very similar to those observed in the present 
Table 1 - Target antigen and clone, dilution, antigen retrieval method, and incubation time and temperature for immunohistochemical staining for Ki-67, p63, Estrogen Receptor (ER), and Progesterone Receptor (PR).

\begin{tabular}{lcccc}
\hline Target Antigen (Clone) & Dilution & Manufacture & Antigen Retrieval Method & Incubation Time (h) / Temperature \\
\hline Ki-67 (MIB-1) & $1: 25$ & Dako & $\begin{array}{c}\text { Pressurised Heat }\left(125^{\circ} \mathrm{C} / 2 \mathrm{~min}\right) \\
\text { with citrate buffer } \mathrm{pH} 6.0\end{array}$ & $1 /$ Room Temperature \\
P63 & $1: 100$ & Neomarkers & $\begin{array}{c}\text { Pressurised Heat }\left(125^{\circ} \mathrm{C} / 2 \mathrm{~min}\right) \\
\text { with citrate buffer } \mathrm{pH} 6.0\end{array}$ & $1 /$ Room Temperature \\
ER (1D5) & $1: 20$ & Dako & $\begin{array}{c}\text { Pressurised Heat }\left(125^{\circ} \mathrm{C} / 2 \mathrm{~min}\right) \\
\text { with EDTA buffer } \mathrm{pH} 9.0\end{array}$ & $1 /$ Room Temperature \\
PR (HPRA2) & $1: 20$ & Neomarkers & $\begin{array}{c}\text { Pressurised Heat }\left(125^{\circ} \mathrm{C} / 2 \mathrm{~min}\right) \\
\text { with EDTA buffer } \mathrm{pH} 9.0\end{array}$ & $1 /$ Room Temperature \\
\hline
\end{tabular}

case (SANT'ANA et al., 2014). Many cases of proliferative mammary changes (hyperplasia and neoplasms) in dogs and cats have been observed in adult animals, usually after previous therapeutic or spontaneous exposure to ovarian hormones (RUTTEMAN, 1990; MISDORP, 2002). Cases of mammary fibroadenomatoid hyperplasia in humans have been confirmed in adult women with mean ages of 32-33 years (HANSON et al., 1987; POULTON et al., 1995) and 58 years (KAMAL et al., 1998) and occasionally in women as young as 24 years (ZHANG et al., 2014).

The main conditions considered in the differential diagnosis in this case included mammary neoplasm and mastitis. Initially, because of the large size of the lesion, a presumptive diagnosis of mammary neoplasm was suggested, but the histopathology associated with the clinical and gross features indicated a diagnosis of mammary fibroadenomatoid hyperplasia. Histological findings observed in the current case are similar to those of a mammary fibroadenoma, which is a frequent neoplasm in young rats and women and has also been reported in a heifer (THIBAULT et al., 1997), a young cow (MINA et al., 1994), and a lamb (GULBAHAR et al., 2007). This benign neoplasm generally forms well-delimited nodules; whereas, fibroadenomatoid hyperplasia is characterized by extensive lesions throughout the mammary glands (HANSON et al., 1987, SANT'ANA et al., 2014), as observed in the current case. This case of bovine mammary hyperplasia appears to have good prognosis because there was no recurrence of the mammary lesions for at least 1 year after surgical excision, as observed in the bubaline mammary fibroadenomatoid hyperplasia (SANT'ANA et al., 2014).

\section{REFERENCES}

BRITO, M.F. et al. Mammary adenocarcinoma in a mare. Ciencia Rural, v.38, p.556-560, 2008. Available from: <http://www.scielo. br/pdf/cr/v38n2/a45v38n2.pdf >. Accessed: Nov. 18, 2016. doi: 10.1590/S0103-84782008000200045.

CASSALI, G.D. et al. Consensus for the diagnosis, prognosis and treatment of canine mammary tumors. Brazilian Journal of Veterinary Pathology, v.4, p.153-180, 2011. Available from: <http://bjvp.org.br/wp-content/uploads/2015/07/ DOWNLOAD-FULL-ARTICLE-29-20881_2011_7_11_14_42. pdf $>$. Accessed: Oct. 11, 2016.

GULBAHAR, M.Y. etal. Mammary fibroadenoma in a lamb. Journal of Veterinary Science, v.8, p. 423-425, 2007. Available from: $<$ http://www.vetsci.org/journal/view.html?uid=443\&vmd=Full $>$. Accessed: Oct. 12, 2016. doi: 10.4142/jvs.2007.8.4.423.

HANSON, C.A. et al. Fibroadenomatosis (fibroadenomatoid mastopathy): a benign breast lesion with composite pathologic features. Pathology, v.19, p.393-396, 1987. Available from: $<$ http://www.pathologyjournal.rcpa.edu.au/article/S00313025(16)36694-6/fulltext>. Accessed: Oct. 11, 2016. doi: $10.3109 / 00313028709103889$

HIRAYAMA, K. et al. Invasive ductal carcinoma of the mammary gland in a mare. Veterinary Pathology, v.40, p.86-91, 2003. Available from: <http://journals.sagepub.com/doi/pdf/10.1354/ vp.40-1-86>. Accessed: Sep. 30, 2016. doi: 10.1354/vp.40-1-86.

HONG, C.B. Mammary nodular hyperplasia in a cow. Journal of Veterinary Diagnostic Investigation, v.6, p.116-118, 1994. Available from: <http://journals.sagepub.com/doi/pdf/1 0.1177/104063879400600125>. Accessed: Sep. 22, 2016. doi: $10.1177 / 104063879400600125$.

KAMAL, M. et al. Fibroadenomatoid hyperplasia: a cause of suspicious microcalcification on mammographic screening. American Journal of Roentgenology, v.171, p.1331-1335, 1998. Available from: <http://www.ajronline.org/doi/pdf/10.2214/ ajr.171.5.9798874>. Accessed: Oct. 15, 2016. doi: 10.2214/ ajr.171.5.9798874.

MANDAL, P.C.; IYER, P.K. Mammary intraductal carcinoma in a buffalo (Bubalus bubalis). Pathologia Veterinaria, v.6, p.534-537, 1969 . 
MINA, R.B. et al. Mammary fibroadenoma in a young Holstein cow. Journal of Veterinary Medicine Science, v.56, p.11711172, 1994.

MISDORP, W. Tumors of the mammary gland. In: MEUTEN, D.J. Tumors in domestic animals. Ames: Iowa State University, 2002. p.575-606.

PEÑA, L.L. et al. Immunohistochemical detection of Ki-67 and PCNA in canine mammary tumors: relationship to clinical and pathologic variables. Journal of Veterinary Diagnostic Investigation, v.10, p.237-246, 1998. Available from: <http:// journals.sagepub.com/doi/pdf/10.1177/104063879801000303>. Accessed: Sep. 30, 2016. doi: 10.1177/104063879801000303.

PEREIRA, P.D. et al. Cell proliferation in feline normal, hyperplastic and neoplastic mammary tissue - an immunohistochemical study. Veterinary Journal, v.168, p.180-185, 2004. Available from: $<$ http:// www.sciencedirect.com/science/article/pii/S1090023303002065>. Accessed: Sep. 22, 2016. doi: 10.1016/j.tvj1.2003.10.018.

POULTON, T.B. et al. Sclerosing lobular hyperplasia of the breast: imaging features in 15 cases. American Journal of Roentgenology, v.165, p.291-294, 1995. Available from: $<$ http://www.ajronline.org/doi/pdf/10.2214/ajr.165.2.7618542>. Accessed: Oct. 15, 2016. doi: 10.2214/ajr.165.2.7618542

POVEY, R.C.; OSBORNE, A.D. Mammary gland neoplasia in the cow. A review of the literature and report of a fibrosarcoma. Pathologia Veterinaria v.6, p.502-512, 1969.
RUTTEMAN, G.R. Hormones and mammary tumour disease in the female dog: an update. In Vivo, v.4, p.33-40, 1990.

SANT'ANA, F.J.F. et al. Mammary diffuse fibroadenomatoid hyperplasia in water buffalo (Bubalus bubalis): three cases. Journal of Veterinary Diagnostic Investigation, v.26, p.453456, 2014. Available from: <http://journals.sagepub.com/doi/ pdf/10.1177/1040638714526595>. Accessed: Nov. 30, 2015. doi: $10.1177 / 1040638714526595$.

SINGH, B.; IYER, P.K.R. Mammary intraductal carcinoma in goats (Capra hircus). Veterinary Pathology, v.9, p.441-446, 1972. Available from: <http://journals.sagepub.com/doi/pdf/1 0.1177/030098587200900604>. Accessed: Sep. 12, 2016. doi: $10.1177 / 030098587200900604$

THIBAULT, S. et al. Mammary fibroadenoma in a heifer. Canadian Veterinary Journal, v.38, p.785-786, 1997. Available from: <https://www.ncbi.nlm.nih.gov/pmc/articles/PMC1576795/ pdf/canvetj00097-0059.pdf>. Accessed: Aug. 19, 2016.

WU, L.S.; CHEN, A.Y. Ultrasound analysis of fibroadenomatoid hyperplasia of the breast. Chinese Journal of Ultrasound Diagnosis, v.2, p.71-73, 2001.

ZHANG, H. et al. Giant fibroadenomatoid hyperplasia of the breast: a case report. Gynecologic and Obstetric Investigation, v.77, p.134-136, 2014. Available from: <https://www.karger. com/Article/Abstract/357443>. Accessed: Oct. 10, 2016. doi: $10.1159 / 000357443$. 